\title{
Overcoming the clarification challenges of high cell density culture
}

\author{
Laura Gimenez", Elie E Kawkabani, Pieter Jacobs, Laetitia Malphettes \\ From 24th European Society for Animal Cell Technology (ESACT) Meeting: C2P2: Cells, Culture, Patients, Products \\ Barcelona, Spain. 31 May - 3 June 2015
}

\section{Introduction}

Cell line engineering and process intensification efforts have led to high performing fed-batch cell culture processes where cell density can reach $>30 \times 106$ cells $/ \mathrm{mL}$. These high performance processes also come with new challenges, in particular developing efficient and scalable primary recovery processes.

Centrifugation coupled with depth filtration is a standard approach for clarification of mammalian cell culture broth. However, with high cell density cultures, it can become challenging to obtain low turbidity clarified cell culture fluid (CCCF), and the filtration surface area required for clarification may become limiting when scaling up.

\section{Objective}

We explored novel clarification strategies for cell culture processes using $\mathrm{CHO}$ cell lines producing monoclonal antibodies, with the goal of removing more impurities during harvest and increasing the robustness of this process step, while opening up possibilities for the reduction of the filtration surfaces.

\section{Determination of flocculation conditions}

All the work described in this abstract was performed on $\mathrm{CHO}$ cell culture processes producing monoclonal antibodies (mAb). Cell density at harvest was 20-30x106 cells $/ \mathrm{ml}$ and viability $60-70 \%$. Turbidity of the cell culture broth at harvest was $>2500 \mathrm{NTU}$.

A positively charged flocculation agent, available in pharmaceutical grade and suitable for GMP manufacturing, was selected. Screening studies were performed at $2 \mathrm{~L}$ scale in order to identify the most suitable flocculant concentration and to study the impact of agitation on the flocculation process. After flocculation, samples were spun down in a dead end centrifuge and turbidity

\footnotetext{
* Correspondence: Laura.Gimenez@ucb.com Biotech Sciences, UCB Pharma, Braine I'Alleud, Belgium of the supernatant was measured as an indicator of flocculation efficiency. Selected conditions were: flocculant concentration $0.0375 \%$; agitation $=100 \mathrm{rpm}$.

\section{Scale-up to $80 \mathrm{~L}$}

The flocculation conditions selected at $2 \mathrm{~L}$ scale were scaled-up to 80L scale, representative of our GMP manufacturing scale. The flocculated broth was processed through disc-stack centrifugation, depth filtration and membrane filtration. The impact on product recovery, product quality, impurity removal and filtration performance was assessed.

\section{Impact on filter capacity \\ Depth filters}

Following disc-stack centrifugation, the broth (mAb 1) was processed through a series of two depth filters. Filtration was performed at constant flow rate. Turbidity of permeate was used to monitor filtration efficiency. Results are shown in Figure 1.

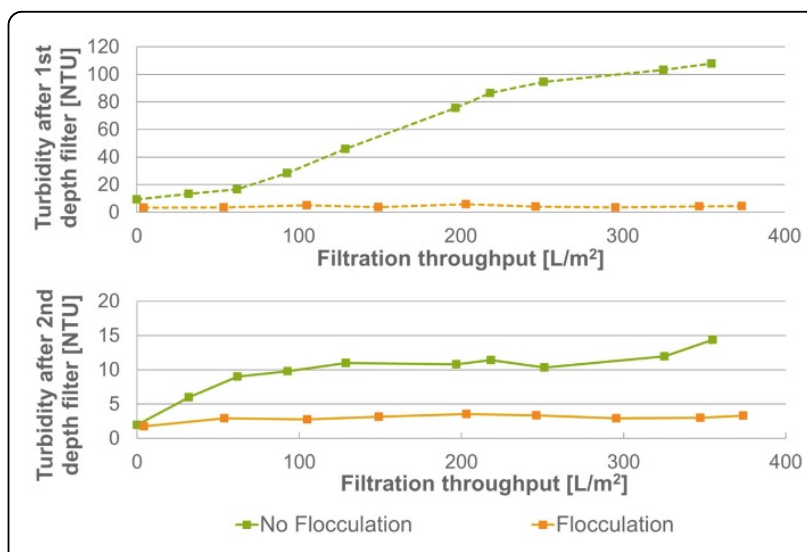

Figure 1 Permeate turbidity according to filtration throughput. 
Table 1. Impact of flocculation on filter capacity and CCCF turbidity

\begin{tabular}{lllll}
\hline & Depth filter capacity $\left[\mathrm{L} / \mathbf{m}^{\mathbf{2}}\right]$ & $\mathbf{0 . 2} \boldsymbol{\mu m}$ filter capacity $\left[\mathrm{L} / \mathbf{m}^{\mathbf{2}}\right]$ & $\mathbf{0 . 1} \boldsymbol{\mu m}$ filter capacity $\left[\mathrm{L} / \mathbf{m}^{\mathbf{2}}\right]$ & CCCF Turbidity $[\mathrm{NTU}]$ \\
\hline No flocculation & 250 & 1018 & 16 & 10 \\
\hline Flocculation & $>350$ & 6500 & 569 & 3 \\
\hline
\end{tabular}

\section{Membrane filters}

The depth filtered material was then processed through bioburden reduction filters of either $0.2 \mu \mathrm{m}$ or $0.1 \mu \mathrm{m}$ cut-off. Maximum filtration throughput was used to determine filtration efficiency. Results are shown in Table 1.

\section{Impact on product recovery and quality}

Impact of flocculation on product recovery and quality was tested for 3 different mAbs. Titer was measured in clarified cell culture fluid by protein A HPLC. Acidic Peak Group (APG) and High Molecular Weight Species (HMWS) levels were measured on Protein A eluate.

It was shown that the addition of the flocculant did not impact product recovery and harvest yield for any of the 3 mAbs tested.

Product quality was also not impacted by the new clarification process.

\section{Impurity removal}

Treated and untreated CCCF (mAb 1) were analyzed in order to evaluate the impact of flocculation on impurity removal prior to downstream purification.

It was shown that the introduction of the flocculant did not affect HCP content, but reduced DNA level by $90 \%$.

\section{Conclusions}

Optimal flocculation agent concentration and agitation conditions were selected at small scale. Flocculation was then successfully introduced into a clarification process representative of GMP manufacturing scale, including disc-stack centrifugation and depth filtration. Flocculation was shown to have no impact on product recovery and quality while enabling to increase impurity removal prior to purification, as well as filtration capacity, improving robustness and scalability of the process. Current work is focusing on studying the impact on chromatography resins and demonstrating clearance of the flocculation agent during downstream process.

\section{Acknowledgements}

The authors would like to acknowledge all the Upstream Process Sciences and Biotech Sciences team members who contributed to the success of this work. Thank you all for your dedication and support, for running the bioreactors, taking part in the filtration studies, performing the analyses and bringing your thoughts and energy to the project.

Published: 14 December 2015
doi:10.1186/1753-6561-9-S9-P35

Cite this article as: Gimenez et al:: Overcoming the clarification

challenges of high cell density culture. BMC Proceedings 2015 9(Suppl 9): P35.
Submit your next manuscript to BioMed Central and take full advantage of:

- Convenient online submission

- Thorough peer review

- No space constraints or color figure charges

- Immediate publication on acceptance

- Inclusion in PubMed, CAS, Scopus and Google Scholar

- Research which is freely available for redistribution

Submit your manuscript at www.biomedcentral.com/submit 